\title{
Interleukins, interferons, and establishment of pregnancy in pigs
}

\author{
Daniel J Mathew ${ }^{1}$, Matthew C Lucy ${ }^{2}$ and Rodney D Geisert ${ }^{2}$ \\ ${ }^{1}$ School of Agriculture and Food Science, University College Dublin, Belfield, Dublin, Ireland and \\ ${ }^{2}$ Division of Animal Sciences, University of Missouri, Columbia, Missouri, USA
}

Correspondence should be addressed to D J Mathew; Email: daniel.mathew@ucd.ie

\begin{abstract}
Early pregnancy in mammals requires complex and highly orchestrated cellular and molecular interactions between specialized cells within the endometrium and the conceptus. Proinflammatory cytokines are small signaling proteins released by leukocytes that augment innate and adaptive immune responses. They are also released by the mammalian trophectoderm as the conceptus apposes the uterine surface for implantation. On approximately day 12 of development in pigs, the conceptus undergoes a rapid morphological transformation referred to as elongation while simultaneously releasing estrogens and a novel conceptus form of interleukin-1 beta (IL1ß). Following elongation, pig conceptuses express interferon gamma (IFN $\gamma$ ) and, in lesser amounts, interferon delta (IFN $\delta$ ). Significant IFN signaling takes place within the endometrium between day 14 and 18 of pregnancy as the conceptus intimately associates with the uterine epithelium. Based on studies carried out in pigs and other mammals, the combined spacio-temporal activities of conceptus estrogens, IL1ß, and IFN set in motion a series of coordinated events that promote establishment of pregnancy. This is achieved through enhancement of conceptus development, uterine receptivity, maternal-fetal hemotropic exchange, and endometrial leukocyte function. These events require activation of specific signaling pathways within the uterine luminal epithelium, glandular epithelium, and stroma. Here, we review proinflammatory cytokine expression by pig conceptuses and the hypothesized actions of these molecules during establishment of pregnancy.

Reproduction (2016) 151 R111-R122
\end{abstract}

\section{Introduction}

The first 3 weeks of development are the most critical for survival of the early mammalian embryo or conceptus (embryo and extraembryonic membranes). During this time, the blastocyst hatches from the zona pellucida exposing the conceptus to a lavish uterine environment that consists of a complex mixture of maternal secretory proteins and small molecular weight molecules. Attachment and implantation follows when the conceptus becomes intimately associated with the uterine luminal epithelium (LE), glandular epithelium (GE), stromal fibroblasts, and maternal immune cells. There is a defined "window" of uterine receptivity, which allows the trophoblast to attach and, in some species, invade beyond the epithelial barrier until pregnancy is established. Throughout the entire process, as many as $25-60 \%$ of conceptuses fail to develop and establish pregnancy, a phenomenon commonly referred to as early embryonic mortality (Wilmut et al. 1986).

Proinflammatory cytokines are small signaling proteins released by leukocytes that control innate and adaptive immune responses. They also mediate communication between the early conceptus and endometrium, promoting implantation and establishment of pregnancy (Simón et al. 1998, Ross et al. 2003a, Granot et al. 2012). Recent clinical observations made during human embryo transfer may reflect the importance of a proinflammatory environment at the site of embryo implantation. It has been shown that mechanically manipulating the endometrium before embryo transfer can be more than double the rate of implantation, pregnancy, and live birth in women who experienced repeated pregnancy failure (Granot et al. 2012). Proinflammatory cytokines, released by the damaged endometrium, are believed to promote implantation.

Interleukins (IL) and interferons (IFN) are some of the most well-studied proinflammatory cytokines in mammalian reproduction. Studies on primates and rodents indicate that the early embryo releases interleukin-1 beta (IL1 $\beta$ ), increasing adhesion molecule expression within the endometrium and invasive characteristics of the cytotrophoblast (Librach et al. 1994, Simón et al. 1998). The pig is unique in that the $I L 1 B$ gene is duplicated, resulting in a novel gene 
and conceptus form of IL1 $\beta$ (interleukin-1 beta 2; IL1 $\beta 2$ ) (Vandenbroeck et al. 1993, Groenen et al. 2012, Mathew et al. 2015). Conceptus expression of IL1 $\beta 2$ is followed by abundant production of interferon gamma (IFN $\gamma$ ) by pig conceptuses and, in lesser concentrations, a pregnancy-specific type I IFN, interferon delta (IFNס) (La Bonnardière et al. 1991). These cytokines are expressed during the synthesis of conceptus estrogens for maternal recognition of pregnancy (Bazer \& Thatcher 1977). Other proinflammatory cytokines are present at the conceptus-maternal interface during establishment of pregnancy in pigs including interleukin-6 (IL6), interleukin-18 (IL18), leukemia inhibitory factor (LIF), and tumor necrosis factor alpha (TNF $\alpha$ ) (Yu et al. 1998, Modrić et al. 2000, Ashworth et al. 2010, Blitek et al. 2012). Many of these cytokines stimulate production and release of prostaglandins (PG) that may contribute to the inflammatory environment within the endometrium (Waclawik 2011, Geisert et al. 2015). The combined spacio-temporal activities of these molecules on specific cell types within the endometrium set in motion a series of coordinated events that promote survival of the early pig conceptus (Bazer \& Johnson 2014).

\section{Development and implantation of the early pig conceptus}

Within 5 days of estrus and breeding, more than 20 pig embryos can enter the uterine lumen. There, the blastocyst hatches from the zona pellucida (day 6-7) and is exposed to the uterine histotroph; a collection of ions and proteins including proteases, growth factors, cytokines, and nutrient transport molecules that are secreted by the uterine LE and GE cells. The histotroph is released in response to ovarian progesterone (P4) and promotes growth and development of the conceptus. The spherical pig blastocyst continues to grow and expand within the uterine lumen until approximately day 11 of gestation. At that time, the conceptus transforms morphologically and rapidly elongates at an extraordinary speed. During rapid elongation, cellular mitosis decreases and cellular hypertrophy and migration of the surrounding trophoblast cells results in extensive remodeling of the conceptus (day 11 or 12; Fig. 1A) (Geisert et al. 1982, Bazer \& Johnson 2014). The pig conceptus becomes ovoid, tubular $(15 \mathrm{~mm}$ by $50 \mathrm{~mm}$ ), and then filamentous ( $1 \mathrm{~mm}$ by $200 \mathrm{~mm}$ ) in less than $3 \mathrm{~h}$, extending through a complex landscape of endometrial crypts and folds at a rate of 30-45 mm/h (Geisert et al. 1982, Bazer \& Johnson 2014). Elongation is a critical stage of development for the early pig conceptus, defining the uterine surface area for its individual placental attachment. The conceptus will continue to grow and expand into the uterine lumen reaching over a meter in length while attaching to the uterine LE between day 13 and 18 of gestation (Bazer \& Johnson
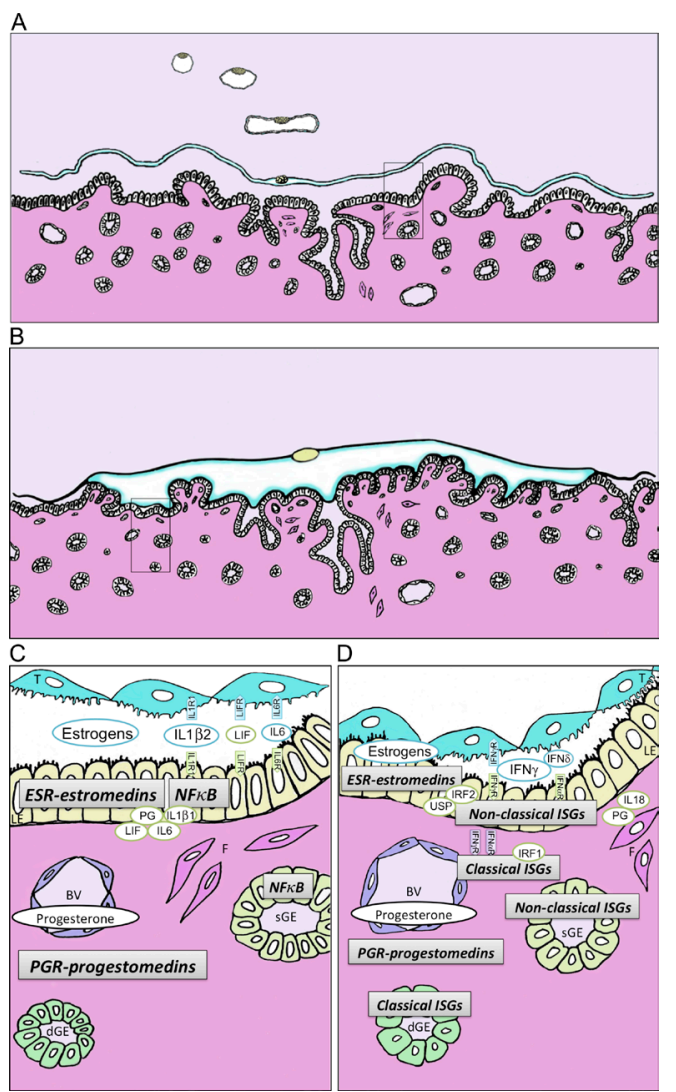

Figure 1 Models representing the proinflammatory cytokine microenvironment created during rapid elongating and implantation of the pig conceptus. Between day 11 and 12 (A and C) and 15 and 18 (B and D) of pregnancy, pig conceptuses rapidly elongate and implant, respectively, along the mesometrium. (C; location of small box in image A) During rapid elongation (near day 12 of pregnancy), pig conceptuses release interleukin-6 (IL6) and abundant concentrations of interleukin-1 beta 2 (IL1 $1 \beta 2$ ) that act on receptors within the conceptus and uterine surface epithelium. Conceptus estrogens and IL1 $\beta 2$ activate estrogen receptor (ESR) and nuclear factor-kappa $B(N F-\kappa B)$ transcription factors, respectively, along the maternal interface likely modulating the expression of prostaglandin (PG) synthases, endometrial interleukin 1 beta 1 (IL1 $1 \beta 1$ ), leukemia inhibitory factor (LIF), and endometrial IL6. (D; location of small box in image B) Near day 15 of pregnancy, pig conceptuses release peak concentrations of interferon gamma (IFN $\gamma$ ) and, in lesser amounts, interferon delta (IFN $\delta$ ). Together, IFN $\gamma$ and IFN $\delta$ trigger the activation of janus-associated kinases and signal transducers and activators of transcription (Jak-STAT) signaling pathways and expression of interferon regulatory factor 1 (IRF1) in stroma fibroblasts (F) and deep glandular epithelium (dGE) that stimulate the expression of classical ISGs. Within the surface epithelium, conceptus estrogens increase the expression of interferon regulatory factor 2 (IRF2), which, in conjunction with ubiquitin-specific protease (USP), may inhibit the expression of classical ISGs. Progestomedins and conceptus IFNs are proposed to induce and stimulate, respectively, the expression of non-classical ISGs within the uterine surface epithelium. Endometrial interleukin-18 (IL18) is released into the uterine lumen and is hypothesized to further stimulate IFN $\gamma$ production by the pig conceptus. T, trophoblast; LE, luminal epithelium; sGE, surface glandular epithelium; BV, blood vessel; IL1R1, interleukin-1 receptor 1; IL6R, interleukin-6 receptor; LIFR, leukemia inhibitory factor receptor; IFN $\gamma \mathrm{R}$, interferon gamma receptor; IFN $\alpha \mathrm{R}$, interferon alpha receptor. 
2014) (Fig. 1B). Within attachment sites, surface area is increased by the presence of endometrial folds, surface epithelial folds, and microvilli between the trophoblast and dome-shaped LE cells, which are coated by a thick glycocalyx (Dantzer 1985, Keys \& King 1990).

The window of receptivity for conceptus attachment is programed by ovarian P4 secretion. In mammals, P4 down-regulates nuclear progesterone receptors (PGR) within the uterine LE and surface GE (sGE) cells (Bazer \& Johnson 2014). Loss of PGR in the pig uterine surface epithelium (Geisert et al. 1994) reduces the expression of mucin-1 (MUC1), a large glycoprotein regulated by P4 that inhibits attachment of the pig conceptus (Bowen et al. 1996). The loss of PGR also allows for the expression of estrogen receptor alpha (ESR1), which can be activated by conceptus estrogens secreted between day 10 and 18 of gestation (Geisert et al. 1993). It is hypothesized that binding of estrogens to surface epithelial ESR1 stimulates the secretion of 'estromedins' such as phosphoprotein 1 (SPP1; also known as osteopontin), fibroblast growth factor 7 (FGF7), and prostaglandin E2 (PGE2) that aid in adhesion, proliferation, and implantation of the pig conceptus (Fig. 1C and D) (Waclawik 2011, Bazer \& Johnson 2014). Although PGR expression decreases in the uterine surface epithelium, expression is unchanged in the stromal fibroblast cells, deep glandular epithelium (dGE), and myometrium (Geisert et al. 1994). Within these tissues, P4 stimulates the release of "progestomedins" that act on the uterine surface epithelium and conceptus (Bazer \& Johnson 2014). During rapid elongation, pig conceptuses also abundantly express a unique form of IL1 $\beta$.

\section{Interleukin-1}

Proinflammatory cytokines IL1 $\beta$ and interleukin-1 alpha (IL1 $\alpha)$ serve as central mediators of inflammation (Sims \& Smith 2010). Hematopoietic cells such as monocytes, macrophages, and skin dendritic cells secrete IL $1 \beta$ during infection. IL1 $\beta$ increases the expression of endothelial cell adhesion molecule and blood vessel permeability, thus allowing peripheral blood leukocytes to extravasate and migrate into infected tissues. Furthermore, IL1 $\beta$ is an endogenous pyrogen, likely contributing to leukocyte proliferation and migration by inducing fever (Sims \& Smith 2010).

The IL1 (IL1 $\beta$ and IL $1 \alpha$ are collectively referred to as IL1) and IL1 receptor family currently consists of 22 molecules that include proinflammatory cytokines IL $1 \beta$ and IL1 $\alpha$, an IL1 receptor antagonist (IL1RA), an IL1 receptor accessory protein (IL1RAP), a functional IL1 receptor (IL1R1), and a decoy receptor the IL1 receptor type 2 (IL1R2) (Sims \& Smith 2010). Release of active IL1 $\beta$ occurs following formation of the inflammasome, a multi-protein complex associated with the caspase- 1 (CASP1) protease, within the cell cytoplasm. Active CASP1 cleaves pro-IL1 $\beta$ and pro-IL18, another member of the IL1 family, resulting in the formation of mature, functional, proinflammatory cytokines.

Binding of IL1 $\beta$ to IL1R1 in the target cell membrane results in juxtapositioning of the toll interleukin-1 receptor (TIR) domains within the cytoplasmic region of IL1R1 and IL1RAP (Sims \& Smith 2010). This effectively recruits myeloid differentiation primary response protein 88, IL-1R-associated kinase 4, tumor necrosis factor receptor-associated factor 6 , and other downstream intermediates. These recruited molecules collectively signal activation of nuclear factor-kappa B (NF-kB) transcription factors and mitogen-activated protein kinases (MAPK) (Sims \& Smith 2010). The abundance of cytokine receptor within a target tissue, including reproductive tissues, can greatly influence the activation of second messenger pathways and cytokine activity.

Nuclear factor-kappa B transcription factors are evolutionarily conserved modulators of gene expression that control cell activity during innate and adaptive immune processes (Hayden \& Ghosh 2012). NF-kB influences the expression of cytokines, growth factors, adhesion molecules, immunoreceptors, antigen presentation molecules, and other transcription factors (Hayden \& Ghosh 2012). For this reason, NF-kB can have a large effect on cell function and its activity is tightly regulated by feedback mechanisms. Uncontrolled, IL1 signaling, and/or NF- $\mathrm{kB}$ activation can lead to autoinflammatory, autoimmune, infectious, and degenerative diseases that include malignant cancer and type II diabetes (Dinarello 2011). For this reason, the IL1-NF-KB signaling pathway is a target in many disease or cancer therapies.

\section{IL1 and reproduction}

Interleukin-1 beta is believed to be an ancient mediator of vertebrate reproduction and placental viviparity. It has been detected within the reproductive tissues of animals using very different reproductive strategies including oviparous, ovuliparous, and aplacental viviparous species (Bird et al. 2002, Jantra et al. 2007). In addition, IL1 $\beta$ is expressed within the placenta of mammalian and non-mammalian vertebrates such as squamite reptiles (Paulesu et al. 2005). In some placental mammals, including primates, rodents, and pigs, considerable IL1 cross talk occurs between the conceptus and endometrium during implantation (Simón et al. 1998, Ross et al. 2003a, Mathew et al. 2015).

In primates and rodents, IL $1 \beta$ is released by the early blastocyst and has a direct effect on uterine receptivity, modulating alpha $\mathrm{V}(\mathrm{AV})$ and beta 3 (B3) integrin subunits within the uterine LE (Simón et al. 1997, 1998). In primates, IL1 $\beta$ may promote cytotrophoblast invasion and can be detected within the villous cytotrophoblast, extravillous intermediate trophoblast, syncytotrophoblast, as well as maternal stromal decidua cells (Librach et al. 1994, Simón et al. 1994). The mouse blastocyst expresses $/ / 1 \mathrm{~b}$ and $/ / 1 r 1$ during early 
pregnancy and induction of decidualization increases I/1 mRNA within the murine endometrium (Choudhuri \& Wood 1993, Krüssel et al. 1997). The importance of IL1 $\beta$ during early pregnancy in mice is unclear. Intraperitonial infusion of IL1RA between day 2.5 and 7 of pregnancy in mice results in implantation failure (Simón et al. 1998). Knockout mice lacking $/ / 1 r 1$ are fertile, however, having only slightly reduced litter sizes (Abbondanzo et al. 1996). Furthermore, mouse conceptuses lacking $/ / 1 b$, $/ / 1 a$, or $/ / 1 b / \| 1$ a develop normally, suggesting that other factors may compensate for the lack of IL1 signaling within the endometrium (Horai et al. 1998).

Tuo et al. (1996) were the first to report that elongating pig conceptuses express IL1 $\beta$, a phenomena that was further characterized by Ross et al. (2003a). In pigs, conceptus expression of $I L 1 \beta$ is maximal at the height of rapid elongation (approximately day 12 of development) but then decreases 2000-fold and is nearly undetectable a few days later (Ross et al. 2003a). During peak expression, $I L 1 \beta$ is one of the most abundant transcripts in the pig conceptus. Intrauterine IL1 $\beta$ protein concentrations approach $4000 \mathrm{ng}$ per uterine horn (Ross et al. 2003b) and can be detected within the uterine lumen between day 12 and 15 of gestation (Ross et al. 2003a).

\section{Novel pig interleukin-1 beta}

The theory that pigs may have an alternate $I L 1 \beta$ gene was proposed more than 20 years ago (Vandenbroeck et al. 1993). This was not confirmed, however, until recent assembly and analysis of the pig genome (Groenen et al. 2012). It is now accepted that two IL1 $\beta$ genes are present within pig chromosome 3: interleukin-1

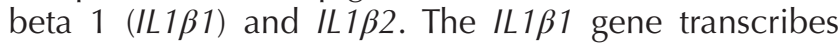
the prototypical cytokine in pigs and is expressed by adult tissues including blood leukocytes and the endometrium (Mathew et al. 2015). The IL1 $\beta 2$ gene is transcribed by the early pig conceptus (Mathew et al. 2015). Conceptus expression of IL1 $\beta 2$ is greatest during elongation; however, transcripts have been detected in the day 6 pig blastocyst (DJ Mathew, MC Lucy and RD Geisert 2015, unpublished observations). Transcripts for $I L 1 \beta 2$ have not been detected in adult tissues, suggesting that expression of this cytokine may be unique to the conceptus (Mathew et al. 2015).

Interleukin-1 beta 2 apparently arose from a gene duplication of IL $1 \beta 1$. The genes are tandem within the chromosome and both have seven exons (Mathew et al. 2015). Compared with $I L 1 \beta 1$, however, $I L 1 \beta 2$ transcribes an alternate exon 1 that is further upstream of exon 2 . As a result, IL1 $1 \beta 1$ spans approximately $7 \mathrm{~kb}$ and $I L 1 \beta 2$, $16.5 \mathrm{~kb}$ (Mathew et al. 2015). In theory, reconfiguration of the IL1B2 adjacent promoter region could have changed its transcriptional regulation and may partially explain why IL $1 \beta 2$ is expressed by the conceptus but not by other pig tissues (Mathew et al. 2015).
IL1 $\beta 1$ and IL1 $\beta 2$ mRNAs are translated into 267 amino acid pro-proteins that are $85 \%$ similar (Mathew et al. 2015). In mammals, CASP1 proteolytically cleaves pro-IL $1 \beta$ in two sequentially conserved locations, resulting in the formation of mature or active IL $1 \beta$ with a molecular weight of approximately $17 \mathrm{kDa}$ (Hailey et al. 2009). Compared with pro-IL1 $\beta 1$, the full-length IL1 $\beta 2$ sequence has an amino acid deletion and insertion, yet retains both CASP1 sites (Mathew et al. 2015).

CASP1 processing of pro-IL1 $\beta 2$, however, may not be the same as for pro-IL1 $\beta 1$. When Degrelle et al. (2009) conducted a proteomic analysis of elongating pig conceptuses, they detected multiple IL1 $\beta$ proteins with varying molecular weight and/or isoelectric points. The detected proteins are likely IL $1 \beta 2$ variants arising from alternate CASP 1 activity or pro-IL $1 \beta 2$ processing by other proteases. In support of this, Katebi et al. (2010) predicted IL1 $\beta 1$ and IL1 $\beta 2$ (pro and mature) protein structures using an iterative threading assembly refinement (I-TASSER) program. They suggest that an amino acid substitution near CASP1 site 2 in pro-IL1 $\beta 2$ could reduce the protease's activity. In addition, we predicted and compared IL1 $\beta 1$ and IL1 $\beta 2$ solvent-accessible surface areas using DNASTAR's latest protein structure assembly program, NovaFold. Visual comparison of the NovaFoldpredicted pro-structures revealed that pro-IL1 $\beta 2$ might have a large steric hindrance partially concealing the first CASP1 site (Fig. 2). In the study by Degrelle et al. (2009), a fully processed IL $1 \beta$ lacking the pro-domain and with a molecular weight of approximately $18 \mathrm{kDa}$ was detected. At least some pro-IL1 $\beta 2$, therefore, may

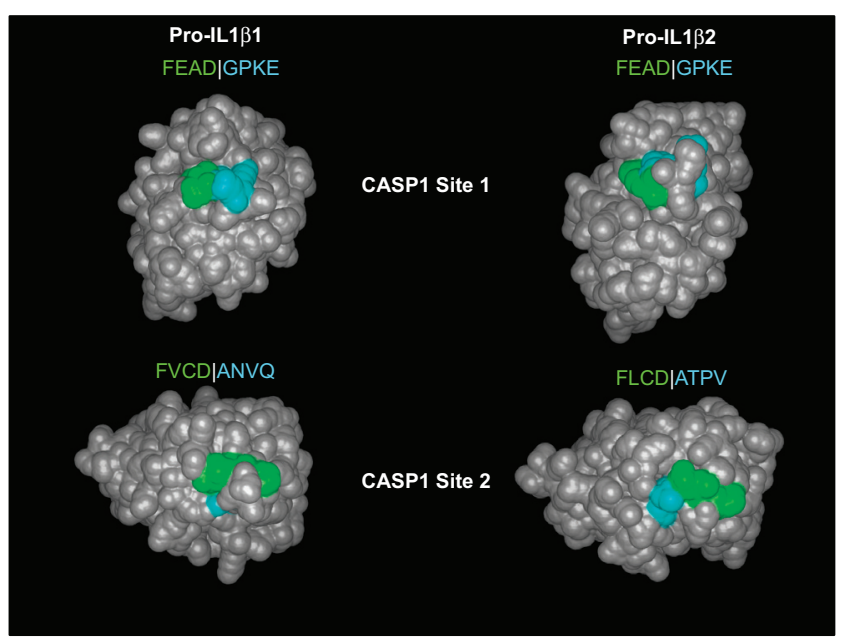

Figure 2 Solvent-accessible surface areas of pro-IL1 $\beta 1$ and pro-IL1 $\beta 2$ protein structures predicted using DNASTAR NovaFold computer program. Four amino acids $\mathrm{N}$-terminal and C-terminal to the CASP1 sites are depicted in green and blue color respectively. Compared with pro-IL1 $\beta 1$, pro-IL1 $\beta 2$ was predicted to have a large steric hindrance, resembling a Y, covering CASP1 site 1 . The opposite was true for CASP1 site 2. Alternatively, a large molecular structure covers CASP1 site 2 in pro-IL1 $\beta 1$ but not pro-IL1 $\beta 2$. The bottom structures are the top structures rotated $180^{\circ}$ around a vertical axis and tilted to the right $90^{\circ}$. 
be proteolytically modified by CASP1 in a manner that is similar to pro-IL1 $\beta 1$.

Fully processed IL $1 \beta 1$ and IL $1 \beta 2$ are $92 \%$ similar within the mature region (Mathew et al. 2015). The high rate of amino acid conservation within this region suggests that mat-IL1 $\beta 2$ also interacts with the IL1R1. Compared with mat-IL1 $\beta 1$, however, mat-IL1 $\beta 2$ was predicted to have three less receptor-binding sites and an inserted proline and four non-conserved amino acid substitutions in locations predicted to interact with the IL1R1 (Fig. 3) (Mathew et al. 2015). Three of these substitutions in matIL1 $\beta 2$ result in a complete change of amino acid sidechain charge and solvent-accessible surface area when compared with mat-IL1 $\beta 1$ (Fig. 3). The second receptorbinding substitution in mat-IL1 $\beta 2$ includes the addition

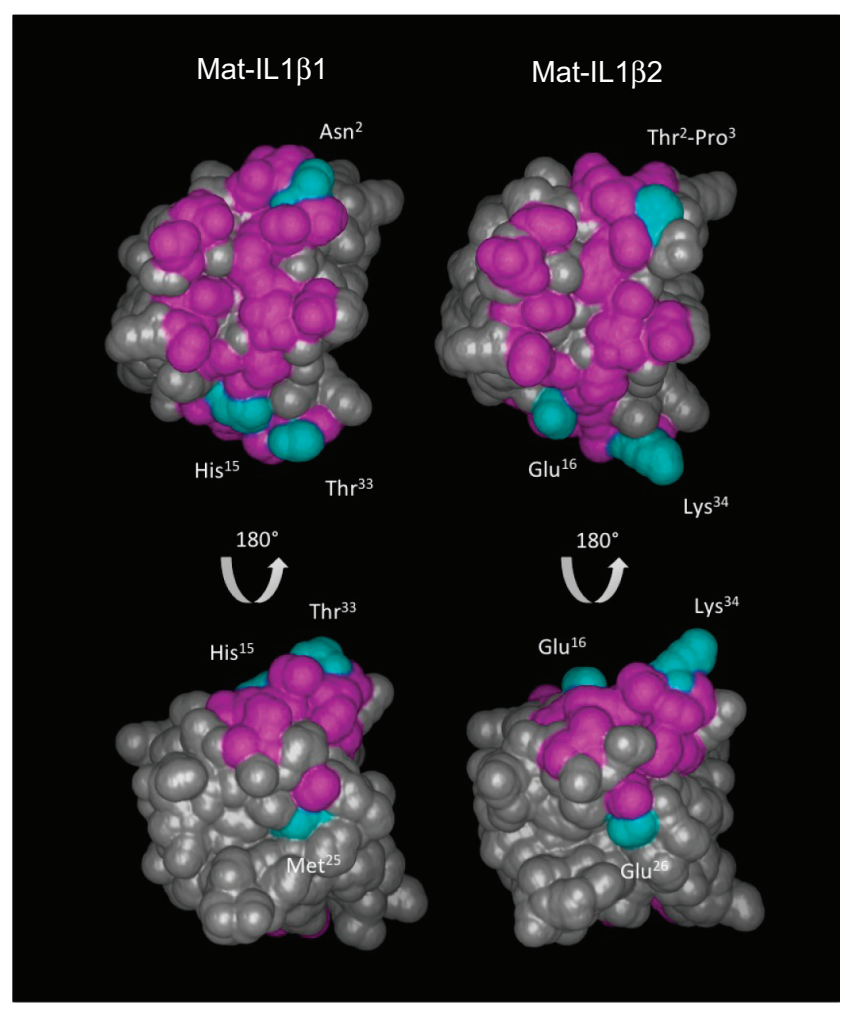

Figure 3 NovaFold-predicted mat-IL1 $\beta 1$ and mat-IL1 $\beta 2$ solventaccessible surface areas (gray, blue, and pink color). Based on interactions with the human IL1R1, NovaFold-predicted 35 binding sites in mat-IL $1 \beta 1$ and 32 in mat-IL $1 \beta 2$ (blue and pink color). All 32 binding sites in mat-IL1 $\beta 2$ were shared with mat-IL1 $\beta 1$. Sequence alignment of mat-IL1 $\beta 1$ with mat-IL1 $\beta 2$ revealed the presence of an inserted proline (residue 2 in mat-IL1 $\beta 2$ ) and five non-conserved amino acid substitutions in the mat-IL1 $\beta 2$ sequence (Mathew et al. 2015). Four of these residues and the inserted proline were predicted to be involved in receptor binding (mat-IL1 $\beta 2$; residues 2, 3, 16, 26, $34)$ and are filled in blue color. The four corresponding residues $(2,15,25$, and 33$)$ in the mat-IL1 $\beta 1$ structure are also filled in blue color. Of these five residues in mat-IL1 $\beta 2$ sequence, three substitutions resulted in a complete change of amino acid side-chain charge and solvent-accessible surface area compared with mat-IL1 $\beta 1$. Glu, glutamine; His, histidine; Pro, proline; Lys, lysine; Thr, threonine; Met, methionine; Asn, asparagine. of a glutamic acid (glutamate; $\mathrm{Glu}^{16}$ ) in place of a histidine (His ${ }^{15}$; mat-IL1B1) with negative- and positivecharged side chains respectively (Fig. 3) (Mathew et al. 2015). Human IL1 $\beta$ has an uncharged glutamine in this location and its mutation to a glycine results in complete loss of receptor-binding activity (Vigers et al. 1997). Based on this information, one might conclude that nonconserved amino acid substitutions in mat-IL1 $\beta 2$ could affect its interaction with the IL1R1 resulting in functional differences between mat-IL1 $\beta 1$ and mat-IL $1 \beta 2$. In further support of this, when the activities of recombinant IL $1 \beta 1$ and IL1 $\beta 2$ were tested during pig endometrial explant experiments, mat-IL1 $\beta 2$ had a lesser capacity to activate NF- $\kappa B$ in uterine LE cells and increase NF- $\kappa B$-responsive gene expression within total endometrium (Mathew et al. 2015).

\section{$I L 1 \beta 2$ and the conceptus}

The autocrine effects of IL1 $\beta 2$ on the pig conceptus are unknown. Pig conceptuses abundantly and temporally express IL1B2, ILIR1, and ILIRAP during rapid elongation and estrogen synthesis for maternal recognition of pregnancy (Fig. $1 \mathrm{~A}$ and $\mathrm{C}$ ). Therefore, it has been suggested that IL1 132 is involved in these processes (Ross et al. 2003a, Degrelle et al. 2009, Mathew et al. 2015). This theory is supported by the observation that IL1 $\beta$ increases aromatase expression and estrogen synthesis in human cytotrophoblast cells (Nester 1993). In addition, after a global proteomic analysis of early pig conceptuses, IL1 $\beta$ was regarded as a focal protein between three primary protein networks that are expressed during rapid elongation (Degrelle et al. 2009). These networks include proteins involved in cellular assembly and organization, embryonic development, as well as cell growth and proliferation. Interleukin-1 beta 2 may promote trophoblast cell reorganization and motility by increasing cell membrane fluidity and/or by modifying actin molecules during rapid elongation (Geisert et al. 1982, 2015). Interleukin-1 beta has been shown to increase the motility of airway epithelial cells, neutrophils, and tumor cells through modifications made to cell integrins and actin filaments (Ma et al. 2014).

\section{IL1 $\beta 2$ and the endometrium}

Pig conceptus IL1 $\beta 2$ may create a proinflammatory microenvironment within the endometrium that promotes implantation and establishment of pregnancy (Fig. 1A and C). Studies suggest that this environment could provide additional histotroph proteins for nourishment of the pre-implanting conceptus, endometrial estrogen, and prostaglandin (PG) synthesis during maternal recognition of pregnancy and endometrial architecture changes for implantation (Table 1) (Ross et al. 2003a, Degrelle et al. 2009, Franczak et al. 2010, 
Table 1 Proinflammatory cytokine, source tissue, location of receptor, proposed actions during establishment of pregnancy, and corresponding references for cytokines detected within the pig conceptus or endometrium during rapid elongation (days 11-12 of pregnancy). ${ }^{a}$

\begin{tabular}{|c|c|c|c|c|}
\hline Cytokine & Source & Receptor location & Proposed actions & Reference \\
\hline \multirow[t]{2}{*}{ IL1 $\beta 1$} & Endometrium & IL1R1 & $\begin{array}{l}\text { Increase endometrial estrogen and PG synthesis } \\
\text { during MRP }\end{array}$ & Franczak et al. $(2010,2013)$ \\
\hline & & $\begin{array}{l}\text { Endometrium and } \\
\text { conceptus }\end{array}$ & Uterine epithelial cell proliferation & Jeong et al. (2015) \\
\hline \multirow[t]{5}{*}{ IL1 $\beta 2$} & Conceptus & IL1R1 & $\begin{array}{l}\text { Alterations to uterine surface architecture for } \\
\text { implantation }\end{array}$ & Geisert et al. (2014) \\
\hline & & & $\begin{array}{l}\text { Modulation of maternal immune responses to } \\
\text { conceptus tissues }\end{array}$ & $\begin{array}{l}\text { Ross et al. (2003a), Mathew et al. } \\
\text { (2015) }\end{array}$ \\
\hline & & $\begin{array}{l}\text { Endometrium and } \\
\text { conceptus }\end{array}$ & $\begin{array}{l}\text { Direct actions on conceptus development } \\
\text { (elongation) }\end{array}$ & $\begin{array}{l}\text { Tuo et al. (1996), Ross et al. } \\
\quad(2003 a, b) \text {, Degrelle et al. (2009) }\end{array}$ \\
\hline & & & $\begin{array}{l}\text { Increase conceptus and endometrial estrogen and } \\
\text { PG synthesis during MRP }\end{array}$ & $\begin{array}{l}\text { Ross et al. (2003a), Franczak et al. } \\
\quad(2010,2013)\end{array}$ \\
\hline & & & $\begin{array}{l}\text { Increase expression of endometrial IL1-stimulated } \\
\text { genes that contribute to conceptus development } \\
\text { and attachment }\end{array}$ & $\begin{array}{l}\text { Tuo et al. (1996), Ross et al. } \\
\text { (2003a), Seo et al. (2011, 2012), } \\
\text { Mathew et al. (2015) }\end{array}$ \\
\hline \multirow[t]{2}{*}{ LIF } & Endometrium & LIFR & $\begin{array}{l}\text { Direct actions on conceptus development and } \\
\text { attachment }\end{array}$ & $\begin{array}{l}\text { Modrić et al. (2000), Blitek et al. } \\
(2012)\end{array}$ \\
\hline & & $\begin{array}{l}\text { Endometrium and } \\
\text { conceptus }\end{array}$ & & \\
\hline \multirow[t]{2}{*}{ IL6 } & $\begin{array}{l}\text { Endometrium and } \\
\text { conceptus }\end{array}$ & IL6R & $\begin{array}{l}\text { Direct actions on conceptus development and } \\
\text { attachment }\end{array}$ & $\begin{array}{l}\text { Modrić et al. (2000), Blitek et al. } \\
\text { (2012) }\end{array}$ \\
\hline & & $\begin{array}{l}\text { Endometrium and } \\
\text { conceptus }\end{array}$ & Endometrial estrogen and PG synthesis during MRP & Franczak et al. (2013) \\
\hline \multirow[t]{2}{*}{ TNF $\alpha$} & Endometrium & TNFR $^{\mathrm{b}}$ & Endometrial estrogen and PG synthesis during MRP & $\begin{array}{l}\text { Yu et al. (1998), Waclawik et al. } \\
\text { (2010), Franczak et al. (2013) }\end{array}$ \\
\hline & & Endometrium & & \\
\hline
\end{tabular}

aIL1, interleukin-1; IL1 $\beta 1$, interleukin-1 beta 1; IL1 $\beta 2$, interleukin-1 beta 2; IL1R1, interleukin-1 receptor type 1; LIF, leukemia inhibitory factor; LIFR, leukemia inhibitory factor receptor; IL6, interleukin-6; IL6R, interleukin-6 receptor; TNF $\alpha$, tumor necrosis factor alpha; TNFR, tumor necrosis factor receptor. ${ }^{b}$ Receptor presence suspected but not verified.

2013, Seo et al. 2011, Mathew et al. 2015). These events are likely triggered, in part, by IL $1 \beta 1$ and IL $1 \beta 2$ activation of extracellular signal-regulated kinases 1 and 2 (ERK1/2), p38 MAPK, and NF-KB within the endometrium (Jeong et al. 2015, Mathew et al. 2015). Studies of immortalized porcine LE cells suggest that IL1 $\beta$ activates p38 MAPK and ERK $1 / 2$ signaling pathways, the latter promoting epithelial cell proliferation (Jeong et al. 2015). In addition, elongating day 12 pig conceptuses or recom- binant IL1 32 can activate the p65 subunit of NF- $\mathrm{\kappa B}$ in pig uterine LE cells (Fig. 4) (Mathew et al. 2011, 2015).

The proinflammatory microenvironment may include an IL1-positive feedback loop involving conceptus IL1 $\beta 2$ and endometrial IL1 $\beta 1$. Elongating pig conceptuses that abundantly express IL $1 \beta 2$ increase the expression of ILIRI and ILIRAP in the adjacent uterine epithelium (Mathew et al. 2011, Seo et al. 2012). In addition, recombinant IL1 $\beta 2$ and recombinant human
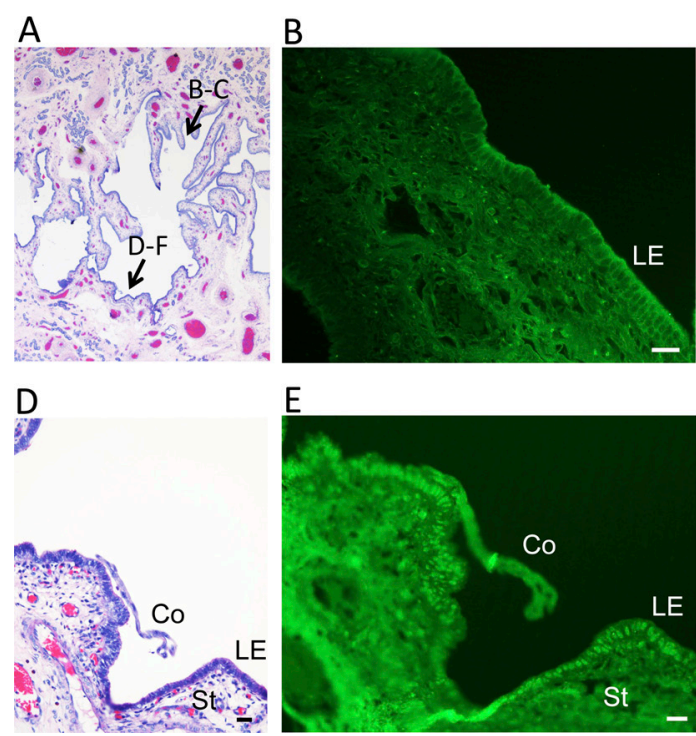

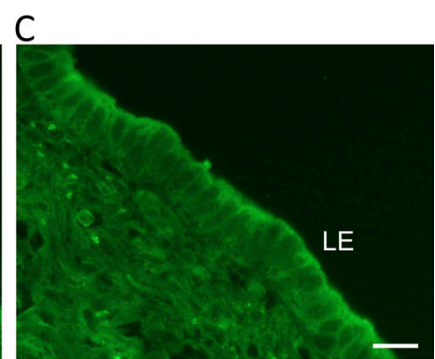

.

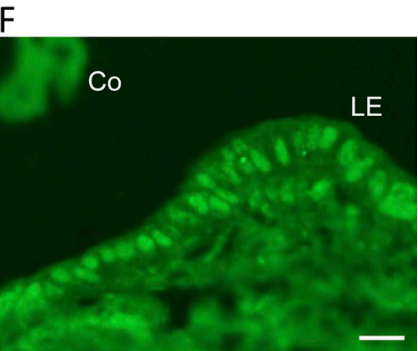

Figure 4 Images of a pig conceptus (Co) on day 12 of pregnancy locally activating the 665 subunit of nuclear factor-kappa B (NF-kB) in uterine luminal epithelial (LE) cells. (A) Image of a hematoxylin and eosin-stained cross section of uterine lumen from a gilt on day 12 of pregnancy, indicating the location where images B-F were taken. (B and C) Image of immunofluorescence for NF-kB in the uterine LE distal to a pig conceptus. (D) Image of a hematoxylin and eosin-stained conceptus attaching to the uterine LE. (E and F) Image of immunofluorescence for NF-kB in LE proximal to the conceptus from image $\mathrm{D}$. The absence of NF- $\kappa B$ nuclear localization in the LE of images $\mathrm{B}$ and $\mathrm{C}$ suggests that pig conceptuses locally activate NF-KB in the adjacent uterine epithelium on day 12 of pregnancy. Black or white bar $=50 \mu \mathrm{m}$. St, stroma. Original image published by Mathew et al. (2011). 
IL1 $\beta$ increase the expression of IL1 $\beta 1$ and IL1 signaling factors (ILIR1 and ILIRAP) in pig endometrial explants respectively (Seo etal. 2012, Mathew et al. 2015). It is well known that IL1 increases blood vessel permeability and leukocyte extravasation in peripheral tissues; therefore, it is possible that IL1 $\beta 1$ and IL1 $\beta 2$ synergistically modulate these processes during implantation in pigs. An increase in endometrial blood vessel permeability is temporally associated with conceptus release of IL1 $\beta 2$ (Keys \& King 1988).

The IL $1 \beta 1$ and IL $1 \beta 2$ feedback loop may be partially controlled by NF- $\mathrm{KB}$ transcription factors activated by IL1 (Ross et al. 2010, Mathew et al. 2015). It is well known that IL1 $\beta$ and NFK $\beta$ subunits are regulated by NF-kB activity. Considering that an over-amplification of the proinflammatory state could have consequences on the establishment of pregnancy, it is possible that reduced activity of IL $1 \beta 2$ helps to minimize the magnitude of the feedback loop.

Involvement of the IL1-NF-kB system during early pregnancy is not unique in pigs. Primate and rodent conceptus IL $1 \beta$ acts on the uterine surface epithelium to promote implantation and the effect is likely mediated by $N F-\kappa B$ transcription factors (Laird et al. 2000, Page et al. 2002, Nakamura et al. 2004, King et al. 2010). NF-kB increases transcripts for prostaglandin synthases and inflammatory cytokines such as prostaglandinendoperoxide synthase 2 (PTGS2), IL6, and LIF that are essential for the establishment of pregnancy (Stewart et al. 1992, Laird et al. 2000, Nakamura et al. 2004). Prostaglandin-endoperoxide synthase 2 is a ratelimiting enzyme during PG synthesis and is essential for the implantation and decidualization in mice (Lim et al. 1997). This may also be true for pigs. Blocking prostaglandin synthesis in pigs results in implantation failure (Kraeling et al. 1985). Pig conceptus IL1 $\beta 2$ may increase endometrial PTGS2 activity by activating NF-кB. Transcripts for PTCS2 increase in uterine LE cells on day 12 of pregnancy and recombinant IL1 $\beta 2$ increased the expression of PTGS2 in endometrial explants that had activated NF-kB (Ashworth et al. 2006, Mathew et al. 2015). Prostaglandins, released by the conceptus and endometrium, have proinflammatory properties and essential functions during implantation (Kennedy et al. 2007, Waclawik 2011, Seo et al. 2014).

\section{IL6 and LIF}

Inflammatory cytokines IL6 and LIF have important functions during implantation in mammals. A decrease in endometrial ILG and LIF mRNAs during early pregnancy in humans is correlated with infertility (Laird et al. 2000) and implantation does not occur in Lif-knockout mice (Stewart et al. 1992). Little is known about the effects of these cytokines during the establishment of pregnancy in pigs. Receptors for IL6 and LIF are expressed by both the conceptus and uterine surface epithelium between day 10 and 14 of pregnancy in pigs, indicating that these cytokines have important functions during implantation (Modrić et al. 2000, Blitek et al. 2012).

Endometrial expression of LIF and IL6 are under control of IL1 and estrogen activation of NF- $\mathrm{KB}$ and ESR transcription factors respectively. Inhibition of NF-KB activity blocks IL1-induced IL6 and LIF expression within cultured human endometrial epithelial cells (Laird et al. 2000) and delays implantation in mice (Nakamura et al. 2004). In the latter study, implantation was partially rescued after uterine viral transfection of Lif cDNA (Nakamura et al. 2004). In mice, ovarian estrogen also increases endometrial Lif expression during implantation, and LIF protein can replace nidatory estrogen by inducing implantation and decidualization (Chen et al. 2000).

Pig conceptus IL1 $\beta 2$ and estrogens may control IL6 and LIF expression within the endometrium. Transcripts for IL6 and LIF increase within the pig endometrium between day 10 and 12 of gestation and in response to conceptus-conditioned culture media (Blitek et al. 2012). Peak concentrations of LIF proteins were detected in pig uterine flushings on day 12 of pregnancy and are temporally associated with conceptus expression of IL $1 \beta 2$ and estrogen synthesis during maternal recognition of pregnancy (Blitek et al. 2012). IL1 $\beta 2$ could theoretically increase the expression of IL6 in conceptus tissues via IL1R1. Transcripts for IL6 were found to transiently increase in pig conceptuses during elongation, a time when ILIRI and ILIB2 are abundant in conceptus tissues (Blitek et al. 2012). Within the endometrium, interactions between transcriptional regulators activated by IL1 $\beta$, such as NF- $\mathrm{kB}$, in combination with those activated by estrogen and progesterone, may be complex yet optimize the adjacent uterine environment for implantation of the pig conceptus (Quaedackers et al. 2007, King et al. 2010).

\section{Interferons}

IFNs are expressed by the peri-implantation primate, rodent, and ungulate trophectoderm and coordinate essential interactions within the uterus during the establishment of pregnancy (Bazer et al. 2009). Conceptus IFNs are the maternal recognition of pregnancy signal in ruminants (cattle, sheep, and goats), acting on the endometrium to indirectly maintain P4 synthesis by the CL (Imakawa et al. 1987, Spencer et al. 2008). Conceptus IFNs also stimulate the expression of classical (antiviral) and non-classical IFN-stimulated genes (ISGs) that are under spacio-temporal regulation within the mammalian endometrium (Spencer et al. 2008). Although the functions of endometrial ISGs remain unclear, studies investigating IFN signaling within the uterus of livestock species suggest that they 
modulate maternal immune tolerance of the implanting conceptus, endometrial architecture changes for uterine receptivity, and vascular remodeling for maternal-fetal nutrient and waste exchange (Table 2).

Mammalian IFNs are classified under two main types: type I and type II. Type I IFNs include interferon alpha $(\alpha)$, beta (IFN $\beta)$, kappa (IFN $\kappa)$, omega $(I F N \omega)$, epsilon $(I F N \varepsilon)$, tau $(I F N \tau)$, and IFN $\delta$. Some type I IFNs consist of more than one subtype; however, all bind the same receptor complex (the interferon alpha receptor (IFN $\alpha R)$ ) to signal a biological response. The type II interferon consists of one member, IFN $\gamma$, which does not share structural similarity with type I IFNs. IFN $\gamma$ has its own receptor complex, the interferon gamma receptor (IFN $\gamma$ R) (Platanias 2005).

Type I and II IFNs trigger the expression of classical ISGs through activation of the janus-associated kinases and signal transducers and activators of transcription (Jak-STAT) signaling pathways. Interferon signaling involves binding of type I and II IFNs to IFN $\alpha$ R and IFN $\gamma R$, respectively, resulting in phosphorylation and activation of STAT (González-Navajas et al. 2012, Bazer 2013). Type I IFN signaling can activate STAT1 and STAT2, resulting in the formation of the interferonstimulated gene factor 3 (ISGF3) complex. The ISGF3 can bind IFN-stimulated response elements (ISRE) within promoter regions of DNA and up-regulate ISGs (González-Navajas et al. 2012, Bazer 2013). Formation of STAT1 dimers during IFN signaling leads to the expression of interferon regulatory factor 1 (IRF1), a protein that can also bind and activate ISREs. There are additional signaling cascades activated by type I and type II IFNs other than Jak-STAT and perhaps explain the pleiotropic effects of these cytokines within the endometrium (González-Navajas et al. 2012, Bazer 2013).

\section{IFN $\gamma /$ IFN $\delta$ and reproduction}

The discovery that IFN $\tau$ serves as the maternal recognition of pregnancy signal in ruminants prompted investigations of IFN signaling within the reproductive tissues of other mammals, including pigs (Imakawa et al. 1987). By 1989, it had been confirmed that antiviral activity could be detected in pig uterine flushings and conceptus-conditioned culture medium between day 12 and 17 of gestation (Cross \& Roberts 1989). It was determined later that pig conceptuses express the type II IFN, IFN $\gamma$, and a newly discovered type I IFN, IFN $\delta$ (Lefèvre et al. 1990, La Bonnardière et al. 1991).

Interferon gamma is the dominate pig conceptus IFN, accounting for $75 \%$ of antiviral activity in uterine flushings compared with IFN $\delta$ ( $25 \%$ of activity). Interferon gamma transcripts are found in conceptus RNAs between day 13 and 20 of development (Joyce et al. 2007a), and peak concentrations of IFN $\gamma$ protein $(250 \mu$ g per uterine horn) are detected in uterine flushings near day 15 of pregnancy (Fig. 1B and D) (Cencič \& La Bonnardière 2002). Interferon gamma protein is released by the trophoblast and has been localized within cytoplasmic vesicles at the cell apical surface (Lefèvre et al. 1990, Joyce et al. 2007a). The proinflammatory cytokine IL18, released by the pig endometrium between day 15 and 18 of gestation, may stimulate conceptus IFN $\gamma$ release (Table 2) (Ashworth et al. 2010). Only transcripts for IFN $\delta$, expressed by the conceptus between day 14 and 20 of development, have been detected (Joyce et al. 2007a).

Interferon gamma receptors are expressed in the day 10 pig conceptus; however, the endometrium is considered to be the primary target ( $\mathrm{D}^{\prime}$ Andréa \& La Bonnardière 1998). Endometrial IFN $\gamma R$ is abundant on day 15 of pregnancy and is temporally associated with peak production of IFN $\gamma$ by conceptuses (D'Andréa \&

Table 2 Proinflammatory cytokine, source tissue, location of receptor, proposed actions during establishment of pregnancy, and corresponding references for cytokines detected within the pig conceptus or endometrium during implantation (days 15-18 of pregnancy). ${ }^{\mathrm{a}}$

\begin{tabular}{|c|c|c|c|c|}
\hline Cytokine & Source & Receptor location & Proposed actions & Reference \\
\hline \multirow[t]{5}{*}{ IFN $\gamma$ and IFN $\delta$} & Endometrium (IFN $\gamma$ ) & IFN $\gamma R$ and IFN $\alpha R^{b}$ & $\begin{array}{l}\text { Increase endometrial ISGs that contribute } \\
\text { to conceptus development and } \\
\text { attachment }\end{array}$ & $\begin{array}{l}\text { Joyce et al. (2007a,b, 2008), } \\
\text { Kim et al. (2012) }\end{array}$ \\
\hline & \multirow[t]{4}{*}{ Conceptus (IFN $\gamma$ and IFN $\delta$ ) } & \multirow[t]{4}{*}{$\begin{array}{l}\text { Endometrium and } \\
\text { conceptus }\end{array}$} & $\begin{array}{l}\text { Endometrial blood vessel modifications for } \\
\text { maternal-fetal hemotropic transport }\end{array}$ & Joyce et al. (2008) \\
\hline & & & Direct actions on conceptus development & $\begin{array}{l}\text { D'Andréa \& La Bonnardière } \\
\text { (1998) }\end{array}$ \\
\hline & & & $\begin{array}{l}\text { Alterations to uterine surface epithelial } \\
\text { architecture during implantation }\end{array}$ & Cencič et al. (2003) \\
\hline & & & $\begin{array}{l}\text { Influence of endometrial leukocyte } \\
\text { function and immune tolerance to } \\
\text { conceptus tissues }\end{array}$ & $\begin{array}{l}\text { Joyce et al. (2008), Kim et al. } \\
\text { (2012) }\end{array}$ \\
\hline IL18 & Endometrium & $\begin{array}{l}\text { IL18 } \mathrm{R}^{\mathrm{b}} \\
\text { Endometrium and } \\
\quad \text { conceptus }\end{array}$ & Conceptus IFN $\gamma$ release & Ashworth et al. (2010) \\
\hline
\end{tabular}

aIFN $\gamma$, interferon gamma; IFN $\delta$, interferon delta; IFN $\gamma \mathrm{R}$, interferon gamma receptor; IFN $\alpha \mathrm{R}$, interferon alpha receptor; IL18, interleukin-18;

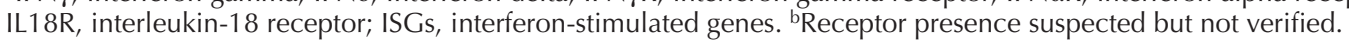


La Bonnardière 1998). Interferon gamma is considered to promote endometrial architectural changes during implantation by modulating the expression of zonula occluden 1 (ZO1), a tight junction protein, along the uterine surface epithelium (Table 2) (Cencič et al. 2003). In addition, conceptus IFNs are transferred across the uterine epithelial barrier and modulate the expression of ISGs within the stroma (Cencič et al. 2003, Joyce et al. 2007a,b, 2008).

\section{Classical and non-classical endometrial ISGs}

Estrogens, released by the conceptus between day 10 and 18 of pregnancy, are the initial maternal recognition of pregnancy signal in pigs (Bazer \& Thatcher 1977, Bazer 2013). Unlike sheep and cattle, IFNs are not antiluteolytic in pigs, and infusion of IFN $\gamma$ and IFN $\delta$ into the pig uterus does not extend the interestrous interval or the functional life span of CL (Lefèvre et al. 1998).

In sheep and cattle, conceptus IFN $\tau$ stimulates classical and non-classical ISGs within the endometrial stroma/dGE and LE/sGE respectively. Within the stroma/ $\mathrm{dGE}$, IRF1 and ISGF3 respond to IFN $\tau$ by modulating the expression of classical ISGs that are believed to be essential for the establishment of pregnancy (Bazer et al. 2009). Within the LE/sGE, IFN $\tau$ stimulates IRF2, a potent inhibitor of IRF1 and ISGF3 activity. The IRF2 blocks the expression of classical ISGs including major histocompatibility complex class 1 polypeptide (MIC), beta 2 microglobulin (B2M), ESR1, and ISGF3 assembly factors (Choi et al. 2001, Spencer et al. 2008). Downregulation of ESR1 prevents luteolysis in sheep (Spencer et al. 2008). IFN $\tau$ and progesterone (via progestomedins) are hypothesized to stimulate and induce, respectively, non-classical ISG expression within the uterine LE/ sGE. This may be achieved through a non-canonical second messenger pathway (independent of the STAT) that includes activation of PI3K and MAPK signaling cascades. Non-classical ISGs that increase in the uterine LE/sGE may affect conceptus development, glucose, and amino acid transport into the lumen and trophoblast attachment during implantation (Bazer et al. 2009).

Classical and non-classical ISGs are differentially regulated within the pig uterus during early pregnancy; however, the mechanism by which this is achieved involves the combined actions of P4, conceptus estrogens, and IFNs. Pig conceptus IFN $\gamma$ and IFN $\delta$ likely act synergistically to activate IRF1 and stimulate the expression of classical ISGs within the uterine stroma/ dGE (Joyce et al. 2007a, Johnson et al. 2009). Stroma expression of IRF1 increases during early pregnancy in pigs and is temporally associated with an increase in classical ISGs localized within the stroma and GE including STAT1, STAT2, myxovirus resistance 1 (MX1), and major histocompatibility complex (MHC) class I and II molecules (Joyce et al. 2007a,b, 2008, Kim et al.
2012). In addition, osmotic pump release of conceptus secretory proteins (CSP) into the pig uterine lumen will increase IRF1 in the stroma (Joyce et al. 2007b). Unlike sheep, estrogens (rather than IFNs) from the porcine conceptus increase the expression of IRF2 within the uterine LE.

In sheep, activation of IRF2 in the uterine LE/sGE blocks the expression of classical ISG STAT1. This does not appear to be true for pigs as conceptus estrogens also increase the expression of STAT1 in this tissue (Joyce et al. 2007a). Later in pregnancy, STAT1 increases within the stroma/dGE in response to pig conceptus IFNs (Joyce et al. 2007a). Activation of STAT1 during early pregnancy may be necessary for endometrial remodeling in the preparation of implantation (Johnson et al. 2009).

\section{Endometrial MHC}

The MHC is responsible for the majority of immune responses during tissue graft rejection. Pig trophoblast cells do not express MHC class I (classical or nonclassical) or class II molecules during implantation (Joyce et al. 2008). This is considered to camouflage the conceptus from maternal immune responses that would be detrimental to conceptus survival. MHC molecules are expressed within the porcine endometrium, however, and are regulated by conceptus IFNs (Joyce et al. 2008).

Joyce et al. (2008) characterized endometrial $\beta_{2} \mathrm{~m}$ and classical (SLA1, SLA2, and SLA3) and non-classical (SLA6, SLA7, and SLA8) MHC class I molecules during the estrous cycle and early pregnancy in pigs. They concluded that pig conceptus IFNs increase MHC class I molecules within the stroma during implantation (day 10-25); however, conceptus estrogens decrease their expression within the LE by up-regulating IRF2 after initial attachment of the trophectoderm. In addition, the decrease in MHC class I molecules in the uterine LE coincides with an increase in the expression of an ubiquitin-specific protease (USP). The USP protein also represses type I IFN signaling and may therefore work with IFR2 in decreasing classical ISGs in the pig uterine surface epithelium (Joyce et al. 2008). Joyce et al. (2008) suggested that loss of $B_{2} m$ and MHC class I molecules along the conceptus-maternal interface could minimize negative immune responses against the conceptus; however, their increase within the stroma may facilitate endometrial vascular changes that support pregnancy. These conclusions are based on the studies in primates and rodents, in which it was found that uterine $\mathrm{NK}$ cells release IFN $\gamma$-promoting uterine vascular modification (Ashkar et al. 2000). In addition, the non-classical MHC class I molecule, HLA-G, regulates angiogenesis during trophoblast invasion in humans (Le Bouteiller et al. 2007). 
MHC class II molecules can present exogenousderived peptides on antigen-presenting cells to $\mathrm{CD}^{+}$ helper T cells. Pig MHC class II molecules, SLA-DQ (A and B), increase in the subepithelial stroma and blood vessels on day 15 of pregnancy and in pig endometrial explants treated with recombinant IFN $\gamma$ (Kim et al. 2012). An increase in endometrial MHC class II molecules in response to IFN $\gamma$ may serve as a means of protecting the mother and conceptus from uterine pathogens. In addition, Kim et al. (2012) speculated that conceptus IFNs increase their expression in the adjacent stroma, facilitating the activation of $\mathrm{CD}^{+} \mathrm{T}$ lymphocytes to promote immune tolerance of the implanting pig conceptus.

\section{Summary and conclusion}

The cellular and molecular interactions that control early pregnancy in mammals are multifaceted and complex; however, common features do exist across species. Ongoing investigations of early pregnancy in primates, rodents, and agricultural animals help to delineate biological pathways that contribute to the establishment of pregnancy or alternatively reproductive failure. During early pregnancy in mammals, proinflammatory cytokines are released by the conceptus and endometrium to promote embryonic survival. In pigs, conceptus IL1 and IFNs likely create a balanced proinflammatory microenvironment within the endometrium by spacio-temporally activating MAPK, NF-KB, and Jak-STAT signaling pathways within the uterine epithelium and stroma. Interleukin-1 beta 2, a newly discovered IL1, may trigger similar pathways in the conceptus, promoting embryonic growth and rapid elongation. In addition, other inflammatory mediators such as LIF, IL6, IL18, and PG may compliment this environment, contributing to embryonic survival and establishment of pregnancy in pigs.

\section{Declaration of interest}

The authors declare that there is no conflict of interest that could be perceived as prejudicing the impartiality of the research reported.

\section{Funding}

Projects mentioned in this review were supported by the National Research Initiative Competitive Grant (2007-3520317836) from the USDA Cooperative State Research, Education, and Extension Service.

\section{References}

Abbondanzo SJ, Cullinan EB, McIntyre K, Labow M \& Stewart C 1996 Reproduction in mice lacking a functional type 1 IL-1 receptor. Endocrinology 137 3598-3601. (doi:10.1210/endo.137.8.8754793)
Ashkar AA, Di Santo JP \& Croy BA 2000 Interferon gamma contributes to initiation of uterine vascular modification, decidual integrity and uterine natural killer cell maturation during normal murine pregnancy. Journal of Experimental Medicine 192 259-270. (doi:10.1084/ jem.192.2.259)

Ashworth MD, Ross JW, Hu J, White FJ, Stein DR, Desilva U, Johnson GA, Spencer TE \& Geisert RD 2006 Expression of porcine endometrial prostaglandin synthase during the estrous cycle and early pregnancy, and following endocrine disruption of pregnancy. Biology of Reproduction 74 1007-1015. (doi:10.1095/biolreprod.105.046557)

Ashworth MD, Ross JW, Stein DR, White FJ, DeSilva UW \& Geisert RD 2010 Endometrial caspase 1 and interleukin-18 expression during the estrous cycle and peri-implantation period of porcine pregnancy and response to early exogenous estrogen administration. Reproductive Biology and Endocrinology 8 33. (doi:10.1186/1477-7827-8-33)

Bazer FW 2013 Pregnancy recognition signaling mechanisms in ruminants and pigs. Journal of Animal Science and Biotechnology 423. (doi:10.1186/2049-1891-4-23)

Bazer FW \& Johnson GA 2014 Pig-blastocyst-uterine interactions. Differentiation 87 52-65. (doi:10.1016/j.diff.2013.11.005)

Bazer FW \& Thatcher WW 1977 Theory of maternal recognition of pregnancy in swine based on estrogen controlled endocrine versus exocrine secretion of prostaglandin F2alpha by the uterine endometrium. Prostaglandins 14 397-401. (doi:10.1016/00906980(77)90185-X)

Bazer FW, Spencer TE, Johnson GA, Burghardt RC \& Wu G 2009 Comparative aspects of implantation. Reproduction 138 195-209. (doi:10.1530/REP-09-0158)

Bird S, Zou J, Wang T, Munday B, Cunningham C \& Secombes CJ 2002 Evolution of interleukin-1 beta. Cytokine Growth Factors Reviews 13 483-502. (doi:10.1016/S1359-6101(02)00028-X)

Blitek A, Morawska E \& Ziecik A 2012 Regulation of expression and role of leukemia inhibitory factor and interleukin-6 in the uterus of early pregnant pigs. Theriogenology 78 951-964. (doi:10.1016/j. theriogenology.2012.05.016)

Bowen J, Bazer F \& Burghardt R 1996 Spatial and temporal analyses of integrin and Muc-1 expression in porcine uterine epithelium and trophectoderm in vivo. Biology of Reproduction 55 1098-1106. (doi:10.1095/biolreprod55.5.1098)

Cencič A \& La Bonnardière C 2002 Trophoblast interferon-gamma: current knowledge and possible role(s) in early pig pregnancy. Veterinary Research 33 139-157. (doi:10.1051/vetres:2002003)

Cencič A, Guillomot M, Koren S \& La Bonnardière C 2003 Trophoblastic interferons: do they modulate uterine cellular markers at the time of conceptus attachment in the pig? Placenta 24 862-869. (doi:10.1016/ S0143-4004(03)00135-8)

Chen JR, Cheng JG, Shatzer T, Sewell L, Hernandez L \& Stewart CL 2000 Leukemia inhibitory factor can substitute for nidatory estrogen and is essential to inducing a receptive uterus for implantation but is not essential for subsequent embryogenesis. Endocrinology 141 4365-4372. (doi:10.1210/endo.141.12.7855)

Choi Y, Johnson GA, Burghardt RC, Berghman LR, Joyce MM, Taylor KM, Stewart MD \& Bazer FW 2001 Interferon regulatory factor-two restricts expression of interferon-stimulated genes to the endometrial stroma and glandular epithelium of the ovine uterus. Biology of Reproduction 65 1038-1049. (doi:10.1095/biolreprod65.4.1038)

Choudhuri R \& Wood G 1993 Production of interleukin-1, interleukin-6 and tumor necrosis factor alpha in the uterus of pseudopregnant mice. Biology of Reproduction 49 596-603. (doi:10.1095/ biolreprod49.3.596)

Cross JC \& Roberts RM 1989 Porcine conceptuses secrete an interferon during the preattachment period of early pregnancy. Biology of Reproduction 40 1109-1118. (doi:10.1095/biolreprod40.5.1109)

D'Andréa S \& La Bonnardière C 1998 Cloning of the porcine interferongamma receptor and its foeto-endometrial expression in early pregnancy. Molecular Reproduction and Development 51 225-234. (doi:10.1002/ (ISSN)1098-2795)

Dantzer V 1985 Electron microscopy of the initial stages of placentation in the pig. Anatomy and Embryology 172 281-293. (doi:10.1007/ BF00318976)

Degrelle SA, Blomberg LA, Garrett WM, Li RW \& Talbot NC 2009 Comparative proteomic and regulatory analysis of the elongating pig conceptus. Proteomics 9 2678-2694. (doi:10.1002/pmic.v9:10) 
Dinarello CA 2011 Interleukin-1 in the pathogenesis and treatment of inflammatory diseases. Blood $\mathbf{1 1 7}$ 3720-3732. (doi:10.1182/ blood-2010-07-273417)

Franczak A, Zmijewska A, Kurowicka B, Wojciechowicz B \& Kotwica G 2010 Interleukin $1 \beta$-induced synthesis and secretion of prostaglandin $E_{2}$ in the porcine uterus during various periods of pregnancy and the estrous cycle. Journal of Physiology and Pharmacology 61 733-742.

Franczak A, Wojciechowicz B \& Kotwica G 2013 Novel aspects of cytokine action in porcine uterus-endometrial and myometrial production of estrone (E1) in the presence of interleukin 1beta (IL1beta), interleukin 6 (IL6) and tumor necrosis factor (TNFalpha)-in vitro study. Folia Biologica 61 253-261. (doi:10.3409/fb61_3-4.253)

Geisert RD, Brookbank JW, Roberts RM \& Bazer FW 1982 Establishment of pregnancy in the pig: II. Cellular remodeling of the porcine blastocyst during elongation of day 12 of pregnancy. Biology of Reproduction 27 941-955. (doi:10.1095/biolreprod27.4.941)

Geisert RD, Brenner RM, Moffatt RJ, Harney JP, Yellin T \& Bazer FW 1993 Changes in oestrogen receptor protein, mRNA expression and localization in the endometrium of cyclic and pregnant gilts. Reproduction Fertility and Development 5 247-260. (doi:10.1071/RD9930247)

Geisert RD, Pratt T, Bazer FW, Mayes JS \& Watson GH 1994 Immunocytochemical localization and changes in endometrial progestin receptor protein during the porcine oestrous cycle and early pregnancy. Reproduction, Fertility and Development 6 749-760. (doi:10.1071/ RD9940749)

Geisert RD, Lucy MC, Whyte J, Ross JW \& Mathew DJ 2014 Cytokines from the pig conceptus: roles in conceptus development in pigs. Journal of Animal Science and Biotechnology 5 51. (doi:10.1186/2049-18915-51)

Geisert RD, Johnson GA \& Burghardt RC 2015 Implantation and establishment of pregnancy in the pig. In Regulation of Implantation and Establishment of Pregnancy in Mammals, pp 137-163. Eds RD Geisert \& FW Bazer. Cham, Switzerland: Springer International Publishing.

González-Navajas JM, Lee J, David M \& Raz E 2012 Immunomodulatory functions of type I interferons. Nature Reviews Immunology 12 125-135. (doi:10.1038/nri3133)

Granot I, Gnainsky Y \& Dekel N 2012 Endometrial inflammation and effect on implantation improvement and pregnancy outcome. Reproduction 144 661-668. (doi:10.1530/REP-12-0217)

Groenen M, Archibald A, Uenishi H, Tuggle C, Takeuchi Y, Rothschild MF, Rogel-Gaillard C, Park C, Milan D \& Megens H 2012 Analysis of pig genomes provide insight into porcine demography and evolution. Nature 491 393-398. (doi:10.1038/nature11622)

Hailey K, Li S, Andersen M, Roy M, Woods V \& Jennings P 2009 Prointerleukin (IL)- $\beta$ shares a core region of stability as compared with mature IL-1 $\beta$ while maintaining a distinctly different configurational landscape: a comparative hydrogen/deuterium exchange mass spectrometry study. Journal of Biological Chemistry 284 26137-26148. (doi:10.1074/jbc. M109.027375)

Hayden M \& Ghosh S 2012 NF-кB, the first quarter-century: remarkable progress and outstanding questions. Genes and Development $26203-$ 234. (doi:10.1101/gad.183434.111)

Horai R, Asano M, Sudo K, Kanuka H, Suzuki M, Nishihara M, Takahashi M \& Iwakura $Y 1998$ Production of mice deficient in genes for interleukin (IL) $-1 \alpha$, IL- $1 \beta$, IL- $1 \alpha / \beta$, and IL- 1 receptor antagonist shows that IL- $1 \beta$ is crucial in turpentine-induced fever development and glucocorticoid secretion. Journal of Experimental Medicine 187 1463-1475. (doi:10.1084/jem.187.9.1463)

Imakawa K, Anthony RV, Kazemi M, Marotti KR, Polites HG \& Roberts RM 1987 Interferon-like sequence of ovine trophoblast protein secreted by embryonic trophectoderm. Nature 330 377-379. (doi:10.1038/330377a0)

Jantra S, Bigliardi E, Brizzi R, Letta F, Bechi N \& Paulesu L 2007 Interleukin 1 in oviductal tissues of viviparous, oviparous and ovuliparous species of amphibians. Biology of Reproduction 76 1009-1015. (doi:10.1095/ biolreprod.107.060095)

Jeong W, Kim J, Bazer FW, Song G \& Jim J 2015 Stimulatory effects of interleukin-1 beta on development of porcine uterine epithelial cell are mediated by activation of the ERK1/2 MAPK cell signaling cascade. Molecular and Cellular Endocrinology 419 225-234. (doi:10.1016/j. mce.2015.10.022)

Johnson GA, Bazer FW, Burghardt RC, Spencer TE, Wu G \& Bayless KJ 2009 Conceptus-uterus interactions in pigs: Endometrial gene expression in response to estrogens and interferons from conceptuses. In Control of Pig Reproduction VIII, pp 321-332. Eds H Rodriguez-Martinez, JL Vallet \& AJ Ziecik. Nottingham, UK: Nottingham University Press.

Joyce MM, Burghardt RC, Geisert RD, Burghardt JR \& Hooper RN 2007a Pig conceptuses secrete estrogen and interferons to differentially regulate uterine STAT 1 in a temporal and cell type specific manner. Endocrinology 148 4420-4431. (doi:10.1210/en.2007-0505)

Joyce MM, Burghardt JR, Burghardt RC, Hooper RN, Jaeger LA, Spencer TE, Bazer FW \& Johnson GA 2007b Pig conceptuses increase uterine interferon regulatory factor-1 (IRF-1), but restrict expression to stroma through estrogen-induced IRF-2 in luminal epithelium. Biology of Reproduction 77 292-302. (doi:10.1095/biolreprod.107.060939)

Joyce MM, Burghardt JR, Burghardt RC, Hooper RN, Bazer FW \& Johnson GA 2008 Uterine major histocompatibility class I molecules and beta 2 microglobulin are regulated by progesterone and conceptus interferons during pig pregnancy. Journal of Immunology 181 2494-2505. (doi:10.4049/jimmunol.181.4.2494)

Katebi AR, Gniewek P, Zimmermann M, Saraswathi S, Gong Z, Tuggle CK, Kloczkowski A \& Jernigan R 2010 Immunological implications of a structural analysis of two different porcine IL1 $\beta$ proteins expressed by macrophages and embryos. In $B C B$ '10 Proceedings of the First ACM International Conference on Bioinformatics and Computational Biology, pp 653-655. New York, NY, USA: Association for Computing Machinery.

Kennedy TG, Gillio-Meina C \& Phang SH 2007 Prostaglandins and the initiation of blastocyst implantation and decidualization. Reproduction 134 635-643. (doi:10.1530/REP-07-0328)

Keys JL \& King GJ 1988 Morphological evidence for increased uterine vascular permeability at the time of embryonic attachment in the pig. Biology of Reproduction 39 473-487. (doi:10.1095/biolreprod 39.2.473)

Keys JL \& King GJ 1990 Microscopic examination of porcine conceptusmaternal interface between days 10 and 19 of pregnancy. American Journal of Anatomy 188 221-238. (doi:10.1002/(ISSN)1553-0795)

Kim M, Seo H, Choi Y, Shim J, Bazer F \& Ka H 2012 Swine leukocyte antigen-DQ expression and its regulation by interferon-gamma at the maternal-fetal interface in pigs. Biology of Reproduction 8643. (doi:10.1095/biolreprod.111.094011)

King A, Collins F, Klonisch T, Sallenave J, Critchley H \& Saunders P 2010 An additive interaction between the NFKB and estrogen receptor signaling pathways in human endometrial epithelial cells. Human Reproduction 25 510-518. (doi:10.1093/humrep/dep421)

Kraeling RR, Rampacek GB \& Fiorello NA 1985 Inhibition of pregnancy with indomethacin in mature gilts and prepubertal gilts induced to ovulate. Biology of Reproduction 32 105-110. (doi:10.1095/ biolreprod32.1.105)

Krüssel JS, Haung H, Wen Y, Kloodt AR, Bielfeld P \& Polan M 1997 Different pattern of interleukin-1 $\beta$-(IL-1 $\beta$ ), interleukin-1 receptor antagonist-(IL$1 \mathrm{ra})$ and interleukin-1 receptor type 1 -(IL-1R tl) mRNA-expression in single preimplantation mouse embryos at various developmental stages. Journal of Reproductive Immunology 34 103-120. (doi:10.1016/S01650378(97)00030-2)

La Bonnardière C, Martinat-Botte F, Terqui M, Lefèvre F, Zouari K, Martal J \& Bazer FW 1991 Production of two species of interferon by large white and meishan pig conceptuses during the peri-attachment period. Journal of Reproduction and Fertility 91 469-478. (doi:10.1530/jrf.0.0910469)

Laird SM, Tuckerman EM, Cork BA \& Li TC 2000 Expression of nuclear factor kappa B in human endometrium; role in the control of interleukin 6 and leukaemia inhibitory factor production. Molecular Human Reproduction 6 34-40. (doi:10.1093/molehr/6.1.34)

Le Bouteiller P, Fons P, Herault JP, Bono F \& Chabot S 2007 Soluble HLA-G and control of angiogenesis. Journal of Reproduction Immunology $\mathbf{7 6}$ 17-22. (doi:10.1016/j.jri.2007.03.007)

Lefèvre F, Martinat-Botte F, Guillomot M, Zouari K \& Charley B 1990 Interferon-gamma gene and protein are spontaneously expressed by the porcine trophectoderm early in gestation. European Journal of Immunology 20 2485-2490. (doi:10.1002/(ISSN)1521-4141)

Lefèvre F, Martinat-Botte F, Locatelli A, Niu PD, Terqui M \& La Bonnardière C 1998 Intrauterine infusion of high doses of pig trophoblast interferons has no antiluteolytic effect in cyclic gilts. Biology of Reproduction 58 1026-1031. (doi:10.1095/biolreprod58.4.1026)

Librach CL, Feigenbaum SL, Bass KE, Cui T, Verastas N, Sadovsky Y, Quigley J, French D \& Fisher S 1994 Interleukin-1 $\beta$ regulates human 
cytotrophoblast metalloproteinase activity and invasion in vitro. Journal of Biological Chemistry 269 17125-17131.

Lim H, Paria B, Das S, Dinchuk J, Langenbach R, Trzaskos J \& Dey S 1997 Multiple female reproductive failures in cyclooxygenase 2-deficient mice. Cell 91 197-208. (doi:10.1016/S0092-8674(00)80402-X)

Ma L, Li X, Zhang S, Yang F, Zhu G, Yuan X \& Jiang W 2014 Interleukin-1 beta guides the migration of cortical neurons. Journal of Neuroinflammation 11 114. (doi:10.1186/1742-2094-11-114)

Mathew DJ, Sellner EM, Green JC, Okamura CS, Anderson LL, Lucy MC \& Geisert RD 2011 Uterine progesterone receptor expression, conceptus development, and ovarian function in pigs treated with RU 486 during early pregnancy. Biology of Reproduction 84 130-139. (doi:10.1095/ biolreprod.110.086843)

Mathew DJ, Newman EM, Guyton JM, Tuggle CK, Geisert RD \& Lucy MC 2015 Activation of the transcription factor nuclear factor kappa-B in uterine luminal epithelial cells by interleukin 1 beta 2 : a novel interleukin-1 expressed by the elongating pig conceptus. Biology of Reproduction 92107 1-13. (doi:10.1095/biolreprod.114.126128)

Modrić T, Kowalski A, Green M, Simmen R \& Simmen F 2000 Pregnancydependent expression of leukaemia inhibitory factor (LIF), LIF receptor- $\beta$ and interleukin-6 (IL-6) messenger ribonucleic acids in the porcine female reproductive tract. Placenta 21 345-353. (doi:10.1053/ plac.1999.0493)

Nakamura H, Kimura T, Ogita K, Koyama S, Tsujie T, Tsutsui T, Shimoya K, Koyama M, Kaneda Y \& Murata Y 2004 Alteration of the timing of implantation by in vivo gene transfer: delay of implantation by suppression of nuclear factor kappaB activity and partial rescue by leukemia inhibitory factor. Biochemical and Biophysical Research Communications 321 886-892. (doi:10.1016/j.bbrc.2004.07.045)

Nester JE 1993 Interleukin-1 stimulates the aromatase activity of human placental cytotrophoblasts. Endocrinology 132 566-570.

Page M, Tuckerman EM, Li TC \& Laird SM 2002 Expression of nuclear factor kappa B components in human endometrium. Journal of Reproductive Immunology 54 1-13. (doi:10.1016/S0165-0378(01)00122-X)

Paulesu L, Romagnoli R \& Bigliardi E 2005 Materno-fetal immunotolerance: is Interleukin-1 a fundamental mediator in placental viviparity? Developmental and Comparative Immunology 29 409-415. (doi:10. 1016/j.dci.2004.09.007)

Platanias LC 2005 Mechanisms of type-I and type-II-interferon-mediated signaling. Nature Reviews. Immunology 5 375-386. (doi:10.1038/ nri1604)

Quaedackers ME, van den Brink CE, van der Saag PT \& Tertoolen LG 2007 Direct interaction between estrogen receptor alpha and NF-kappaB in the nucleus of living cells. Molecular and Cellular Endocrinology 273 42-50. (doi:10.1016/j.mce.2007.05.002)

Ross JW, Malayer JR, Ritchey JW \& Geisert RD 2003a Characterization of the interleukin-1 $\beta$ system during porcine trophoblastic elongation and early placental attachment. Biology of Reproduction 69 1251-1259. (doi:10.1095/biolreprod.103.015842)

Ross JW, Ashworth MD, Hurst AG, Malayer JR \& Geisert RD 2003b Analysis and characterization of differential gene expression during rapid trophoblastic elongation in the pig using subtractive suppression hybridization. Reproductive Biology and Endocrinology $\mathbf{1} 23$. (doi:10.1186/1477-7827-1-23)

Ross JW, Ashworth M, Mathew D, Reagan P, Ritchey J, Hayashi K, Spencer TE, Lucy M \& Geisert RD 2010 Activation of the transcription factor, nuclear factor kappa-B, during the estrous cycle and early pregnancy. Reproductive Biology and Endocrinology 839. (doi:10.1186/1477-7827-8-39)

Seo H, Kim M, Choi Y \& Ka H 2011 Salivary lipocalin is uniquely expressed in the uterine endometrial glands at the time of conceptus implantation and induced by interleukin 1 beta in pigs. Biology of Reproduction $\mathbf{8 4}$ 279-287.

Seo H, Choi Y, Shim J, Choi Y \& Ka H 2012 Regulatory mechanism for expression of IL1B receptors in the uterine endometrium and effects of IL1B on prostaglandin synthetic enzymes during the implantation period in pigs. Biology of Reproduction 87 1-11. (doi:10.1095/ biolreprod.112.101691)

Seo H, Choi Y, Shim J, Yoo I \& Ka H 2014 Comprehensive analysis of prostaglandin metabolic enzyme expression during pregnancy and the characterization of AKR1B1 as a prostaglandin F synthase at the maternal-conceptus interface in pigs. Biology of Reproduction 90 1-13. (doi:10.1095/biolreprod.113.115535)

Simón C, Frances A, Piquette G, Hendrickson M, Milki A \& Polan M 1994 Interleukin-1 system in the maternal trophoblast unit in human implantation: Immunohistochemical evidence for autocrine/ paracrine function. Journal of Clinical Endocrinology \& Metabolism 8 847-854. (doi:10.1210/jcem.78.4.8157710)

Simón C, Gimeno MJ, Mercader A, O'Connor JE, Remohi J, Polan M \& Pellicer A 1997 Embyronic regulation of integrins beta 3, alpha 4 and alpha 1 in human endometrial epithelial cells in vitro. Journal of Clinical Endocrinology and Metabolism 82 2607-2616. (doi:10.1210/ jcem.82.8.4153)

Simón C, Valbuena D, Krüssel J, Bernal A, Murphy CR, Shaw T, Pellicer A \& Polan ML 1998 Interleukin-1 receptor antagonist prevents embryonic implantation by a direct effect on the endometrium epithelium. Fertility and Sterility 70 896-906. (doi:10.1016/S0015-0282(98)00275-1)

Sims JE \& Smith DE 2010 The IL-1 family: regulators of immunity. Nature Reviews Immunology 10 89-102.

Spencer TE, Sandra O \& Wolf E 2008 Genes involved in conceptusendometrial interactions in ruminants: insights from reductionism and thoughts on holistic approaches. Reproduction 135 165-179. (doi:10.1530/REP-07-0327)

Stewart C, Kaspar P, Brunet L, Bhatt H, Gadi I, Köntgen F \& Abbondanzo SJ 1992 Blastocyst implantation depends on maternal expression of leukemia inhibitory factor. Nature 359 76-79. (doi:10.1038/359076a0)

Tuo W, Harney JP \& Bazer FW 1996 Developmentally regulated expression of interleukin- $1 \beta$ by peri-implantation conceptuses in swine. Journal of Reproductive Immunology 31 185-198. (doi:10.1016/01650378(96)00975-8)

Vandenbroeck K, Fiten P, Beuken E, Martens E, Janssen A, Van Damme J, Opdenakker G \& Billiau A 1993 Gene sequence, cDNA construction, expression in Eschericia coli and genetically approached purification of porcine interleukin-1B. European Journal of Biochemistry 217 45-52. (doi:10.1111/j.1432-1033.1993.tb18216.x)

Vigers G, Anderson L, Caffes P \& Brandhuber B 1997 Crystal structure of the type-1 interleukin-1 receptor complexed with interleukin-1 $\beta$. Nature 386 190-194. (doi:10.1038/386190a0)

Waclawik A 2011 Novel insights into the mechanisms of pregnancy establishment: regulation of prostaglandin synthesis and signaling in pigs. Reproduction 142 389-399. (doi:10.1530/REP-11-0033)

Waclawik A, Blitek A \& Ziecik AJ 2010 Oxytocin and tumor necrosis factor alpha stimulate expression of prostaglandin E2 synthesis and secretion of prostaglandin E2 by luminal epithelial cells of the porcine endometrium during early pregnancy. Reproduction 140 613-622. (doi:10.1530/REP10-0092)

Wilmut I, Sales D \& Ashworth C 1986 Maternal and embryonic factors associated with prenatal loss in mammals. Journal of Reproduction and Fertility 76 851-864. (doi:10.1530/jrf.0.0760851)

Yu Z, Gordon JR, Kendall J \& Thacker PA 1998 Elevation in tumour necrosis factor-alpha (TNF-alpha) messenger RNA levels in the uterus of pregnant gilts after oestrogen treatment. Animal Reproductive Science 50 57-67. (doi:10.1016/S0378-4320(97)00081-X)

Received 26 January 2016

First decision 29 February 2016

Revised manuscript received 15 March 2016

Accepted 21 March 2016 